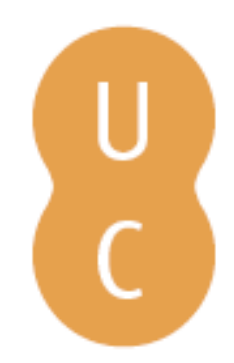

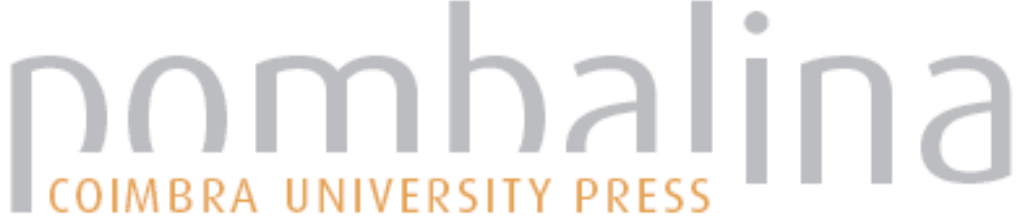

\section{A estratégia política através da hagiografia}

Autor(es): $\quad$ Rebelo, António Manuel R.

Publicado por: Imprensa da Universidade de Coimbra

URL

persistente: URI:http://hdl.handle.net/10316.2/32572

DOI: $\quad$ DOI:http://dx.doi.org/10.14195/978-989-26-0442-8_8

Accessed : $\quad$ 9-Sep-2019 14:52:11

A navegação consulta e descarregamento dos títulos inseridos nas Bibliotecas Digitais UC Digitalis, UC Pombalina e UC Impactum, pressupõem a aceitação plena e sem reservas dos Termos e Condições de Uso destas Bibliotecas Digitais, disponíveis em https://digitalis.uc.pt/pt-pt/termos.

Conforme exposto nos referidos Termos e Condições de Uso, o descarregamento de títulos de acesso restrito requer uma licença válida de autorização devendo o utilizador aceder ao(s) documento(s) a partir de um endereço de IP da instituição detentora da supramencionada licença.

Ao utilizador é apenas permitido o descarregamento para uso pessoal, pelo que o emprego do(s) título(s) descarregado(s) para outro fim, designadamente comercial, carece de autorização do respetivo autor ou editor da obra.

Na medida em que todas as obras da UC Digitalis se encontram protegidas pelo Código do Direito de Autor e Direitos Conexos e demais legislação aplicável, toda a cópia, parcial ou total, deste documento, nos casos em que é legalmente admitida, deverá conter ou fazer-se acompanhar por este aviso.

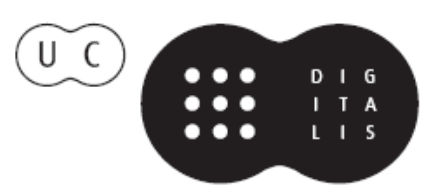


Aurelio Pérez Jiménez, Joșé Ribeiro Ferreira

e Maria do Céu Fialho

(COORdinadores)

\section{Adminiftri Principum.}

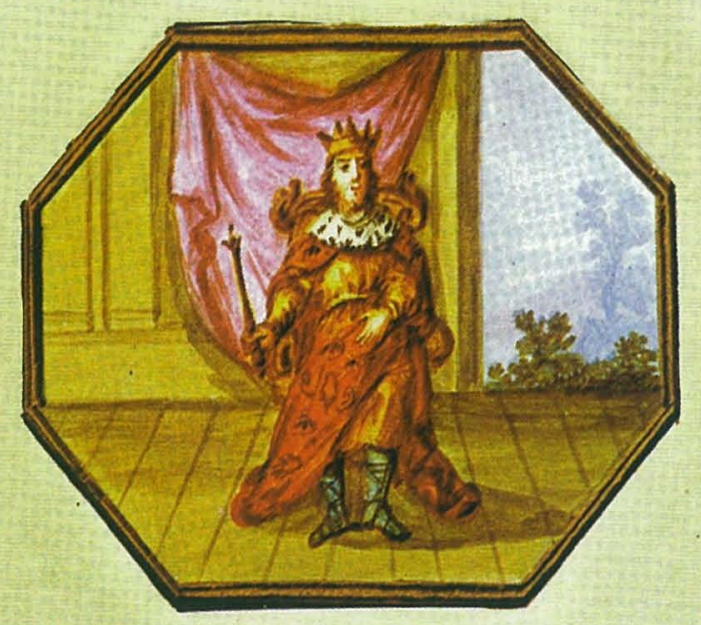

\section{EMBLEM A LIV.}

En tibi plura gerit, quàm lumina prabuit Argos Rex; Aures totidem, quin totidemó, manus. Hec opus Imperio, fidis fupplenda Minijtris, Regi bi funt aures: lumina clara, manus.

\section{- Retrato e a Biografia como estratégia de teorização política}

IMPRENSA DA UNIVERSIDADE DE COIMBRA

Universidad de MálaGa 
(Página deixada propositadamente em branco) 
Aurelio Pérez Jiménez

José RIBEIRo FERREIRA

Maria do Céu Fialho

O RETRATO LITERARIO E A BIOGRAFIA COMO ESTRATÉGIA

\section{DE}

TEORIZACCÃO POLITICA

IMPRENSA DA UNIVERSIDADE DE COIMBRA

UnIVERSIDAD DE MÁlaGa

2004 
Obra publicada com a colaboração de:

Centro de Estudos Clássicos e Humanísticos (Universidade de Coimbra)

International Plutarch Society

Primera edição, Junho de 2004

(c) IMPRENSA DA UnIVERSIDADE DE COIMBRA

(c) Área de Filología Griega. Universidad de Málaga

Coordenação editorial:

Imprensa da Universidade de Coimbra

Área de Filología Griega de la UMA

ISBN: 972-8704-25-9 (PORTUGAL)

ISBN: 84-608-0166-7 (ESPANHA)

Depósito Legal: MA-1420

Impresso em Espanha

Execução gráfica:

IMAGRAF IMPRESORES, S.A.

c/ Nabucco 14

29006 Málaga

Tfno. 952328597

Página de rosto:

"Dos Princepes Transùmptos verdadeiros": Francisco António Novaes Campos, Principe perfeito. Emblemas de D. Joâo de Solórzano. Edição fac-similada do manuscrito da Biblioteca Nacional do Rio de Janeiro oferecido ao Príncipe D. João em 1790 (Prefácio, introdução, comentário e índices por Maria Helena de Teves Costa Ureña Prieto), Instituto de Cultura e Língua Portuguesa, Lisboa, 1985, Emblema LIV, p. 114. 


\title{
A eSTRatégia POlítiCa ATRAVÉS da hagiografia
}

\author{
António Manuel R. Rebelo \\ Universidade de Coimbra
}

Ao falarmos sobre a importância política da hagiografia devemos entender o conceito de "política" na sua acepção mais vasta, i. e. não apenas civil, mas também religiosa. A política religiosa visa determinadas necessidades pastorais, nomeadamente a evangelização ou os meios que possam conduzir à vivência evangélica, começando pela fundamentação doutrinária, no âmbito da filosofia e da teologia. A algumas vertentes deste tipo de "política religiosa" que especifica as variadas abrangências do amplo conceito de evangelização (ou de missão) dá a Igreja Católica hoje a designação de "pastoral". Há, portanto, que ter em conta todos estes matizes que o termo "política" pode revestir. A hagiografia subordina-se sempre a uma finalidade específica, que, por sua vez, se integra numa dimensão política, entendida esta no seu sentido mais lato ${ }^{1}$.

As finalidades concretas do texto hagiográfico são variadas. O primeiro manifesto doutrinário, por assim dizer, da biografia latina cristã encontra-se no prefácio da Passio SS. Perpetuae et Felicitatis. São aí enunciados os seguintes objectivos:

a) honrar a Deus (Deus honoretur);

b) confortar o homem (homo confortetur);

1 Ao abordar a história da redacção dos textos hagiográficos durante a Idade Média latina, Grégoire principia justamente dizendo: "La redazione dei testi agiografici medievali dipende dalla finalità di questa letteratura e dal suo ruolo ecclesiale o politico". $V d$. Réginald Grégoire, Manuale di agiologia. Introduzione alla letteratura agiografica (Bibliotheca Montisfani, 12), Fabriano, 1987, p. 189.

A. Pérez Jiménez, J. Ribeiro Ferreira, Maria do Céu Fialho (edd), O retrato literário e a biografia como estratégia de teorização política, Coimbra-Málaga, 2004, pp. 131-158. 
c) conciliar os uetera fidei exempla do Antigo e Novo Testamentos com os noua documenta do Cristianismo;

d) servir de testemunho para os não-crentes (non credentibus in testimonium);

e) ser um benefício para os crentes (credentibus in beneficium).

Ao longo dos séculos, esses propósitos iniciais foram evoluindo e o género hagiográfico passou a abranger uma panóplia de interesses, mais ou menos evidentes. Assim, além de descrever e glorificar a vida e obra do santo, a sua morte e milagres, contribuindo, deste modo, de forma indirecta para a glória de Deus, mas também para edificação do crente, a hagiografia aponta para objectivos porventura menos óbvios: morais, catequéticos, parenéticos, apologéticos, dogmáticos, eclesiásticos, pastorais, políticos... Na evolução da biografia clássica para a hagiografia, podemos dizer com Grégoire que "la letteratura di «propaganda» diviene in questo modo una letteratura di «edificazione»; la «politica» diviene «teologia»; la deontologia si evolve in apologetica"2.

Por outro lado, esta vertente pragmática da hagiografia obriga a perspectivar a actividade hagiográfica no fenómeno hagiológico, mais vasto, com o qual ela estabelece laços inequívocos e indissolúveis. A hagiografia é, pois, indissociável do contexto religioso, político e sócio-cultural do santo biografado: do seu local de culto, da sua terra natal, da sua família, da nação a que pertenceu, da ordem ou movimento religioso onde professou, das intenções ou interesses dos promotores da sua causa, do autor da hagiografia ou de quem a encomendou. É nesse sentido que Réginald Grégoire declara que a hagiografia é uma "historiografia apologética, dotada de uma finalidade didáctica, elaborada sobre a noção de virtude pessoal e social, individual e colectiva"3.

Ora, a hagiografia e, de modo particular, a forma de retratar o herói da fé situa-se numa tradição não apenas literária, mas também filosófica, reveladora de fortes afinidades e até de influência directa da Antiguidade pagã.

Quanto ao retrato em si, caracterizando-se o santo por levar a extremos heróicos o cumprimento das virtudes, perguntamos: que virtudes? Naturalmente pensamos de imediato nas virtudes cardeais: iustitia, prudentia, fortitudo e moderatio (ou temperantia). Todavia, estas já haviam sido elencadas por Cícero (De Finibus 5.23.67), o qual, por sua vez, retomava as quatro virtudes enunciadas por Platão

2

Id. ibid., p. 209.

3 Id., ibid., p. 13. 


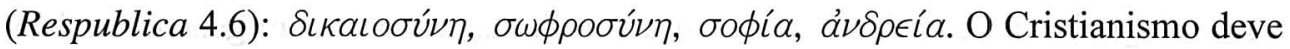
a Santo Ambrósio a recuperação destas virtudes clássicas, emanadas da natura, i. e. da $\phi \dot{v} \sigma \iota s$, e que ele qualifica, pela primeira vez, de cardeais ${ }^{4}$. As virtudes que a alma gera a partir da graça divina - e não a partir da natura - são as teologais: fé, esperança e caridade.

A influência da filosofia clássica, designadamente do estoicismo, é combinada com a herança bíblica do Decálogo, filtrada pela interpretação neo-testamentária que o próprio Cristo lhe confere, com o Sermão da Montanha, com as obras de misericórdia e com os conselhos de $\mathrm{S}$. Paulo em algumas das suas cartas.

Às sete virtudes opõem-se sete uitia ou pecados capitais ${ }^{5}$, alguns dos quais já evidenciavam raízes estóicas. Os famosos catálogos de virtudes da hagiografia eram organizados em função da prática em grau heróico dessas virtudes ${ }^{6}$, tanto pela positiva, como pela negativa. Daí que o santo se afirme como tal, ora abraçando as virtudes, ora repelindo os uitia. Não esqueçamos, por outro lado, que o catálogo de virtudes, processo estilístico tão típico da literatura hagiográfica, já existia na literatura panegírica e foi daí que os hagiógrafos o importaram ${ }^{7}$.

Efectivamente, quanto ao género literário em si, a hagiografia dependia dos modelos clássicos da biografia, do panegírico, da laudatio funebris e da apologia ${ }^{8}$. Note-se

Sobre as características específicas do catálogo de virtudes $v d$. L. von Hertling, "Der mittelalterliche Heiligentypus nach der Tugendkatalogen", Zeitschrift für Ascese und Mystik 8 (1933) 260-268.

Exemplo bem expressivo da utilização do catálogo de virtudes é Sidónio Apolinar, que se dedicou, nos seus poemas, a celebrar os grandes do seu tempo. Na sua composição hendecassilábica Nenia funebris (MGH AA, 8, Ep. 2.8, vv. 5 sq), em honra da matrona Philomatia, louva a homenageada mediante qualificativos que fazem lembrar a terminologia hagiográfica:

O splendor generis, decus mariti, prudens, casta, decens, seuera, dulcis.

Sobre a tradição da biografia romana e a sua influência sobre a hagiografia, $v d$. F. Leo, Die griechisch-römische Biographie nach ihrer litterarischen Form, Leipzig, 1901 (reimpr. Hildesheim, 1965); D. R. Stuart, Epochs of Greek and Roman Biography, Berkeley-London, 1928 (reimpr. New York, 1967); G. Luck, "Die Form der suetonischen Biographie und die frühen Heiligenviten", Mullus. Festschrift Theodor Klauser (= Jahrbuch für Antike und Christentum, Ergänzungsband I), Münster i. W., 1964, 230-241; 
que a biografia não constituía, nem nunca constituiu, só por si, um género literário, ainda que a historiografia fosse o seu grande rival; tão-pouco se confinava apenas à prosa $^{9}$. As designações das diferentes obras biográficas confirmam essa diversidade: Vitae, actus, gesta, libri de uiris illustribus, collationes (i. e. vidas paralelas), legenda, speculum, chronica, commentarii de uita ou de rebus gestis, passio e até elegia, à imitação de Ovídio ${ }^{10}$. Já na Antiguidade o conceito de biografia era objecto de grande controvérsia e não havia unanimidade quanto à definição das suas características, dos objectivos pragmáticos, etc. ${ }^{11}$ Portanto, sob a mesma designação coabitavam, por vezes, mais do que um género literário. A hagiografia era um de entre vários géneros que corporizavam uma tradição biografista mais vasta.

Ora, nas influências biográficas sobre a hagiografia, merece particular relevo a oração fúnebre. É facto comummente aceite que a hagiografia tem as suas origens nos elogios fúnebres ${ }^{12}$. O seu estilo prestava-se a desenvolver lugares comuns que

B. R. Voss, "Berührungen von Hagiographie und Historiographie in der Spätantike", Frühmittelalterliche Studien 4 (1970) 53-69; Martin Heinzelmann, "Neue Aspekte der biographischen und hagiographischen Literatur in der lateinischen Welt (1.-6. Jahrhundert)", Francia 1 (1973) 27-44; S. Calderone, "Moduli della biografia classica nella biografia cristiana" Mondo classico e cristianesimo, Roma, 1982, pp. 133-139.

Cf. Jozef Ijsewijn, "Die Humanistische Biographie", Biographie und Autobiographie in der Renaissance. Arbeitsgespräch in der Herzog August Bibliothek Wolfenbüttel vom 1. bis 3. November 1982, Vorträge hrsg. v. August Buck, Wiesbaden, 1983, 1-19, particularmente p. 2. No caso da hagiografia, chegaram até nós muitas uitae metricae e passiones metricae

Convém lembrar que, embora a designação de $\beta$ เoүp $\alpha \phi i ́ \alpha$ remonte a meados do primeiro milénio da nossa era, o termo é moderno, mesmo na língua latina. Em todo o caso, é posterior ao séc. XVII. Cf. Jozef Ijsewijn, "Die Humanistische Biographie”, Biographie und Autobiographie in der Renaissance. Arbeitsgespräch in der Herzog August Bibliothek Wolfenbüttel vom 1. bis 3. November 1982, Vorträge hrsg. v. August Buck, Wiesbaden, 1983, 1-19, particularmente p. 3 e notas 7-9.

Tácito, por exemplo, considera o seu Agricola ora biografia, ora historiografia. Vd. sobre esta matéria Albrecht Dihle, “Tacitus' Agricola und das Problem der historischen Biographie", Der Altsprachliche Unterricht 31.5 (1988) $42-52$ e uma análise mais profunda de toda esta problemática em Albrecht Dihle, Die Entstehung der historischen Biographie, Heidelberg, 1987.

12 Vd. Dieter von der Nahmer, Die lateinische Heiligenvita. Eine Einführung in die lateinische Hagiographie (Das lateinische Mittelalter), Darmstadt, 1994, pp. 58 e 69 sq; e A. A. R. Bastiaensen, "Jérôme hagiographe", Hagiographes (Corpus Christianorum; ed. Guy Philippart), sous la direction de..., 2 vols, Turnhout, 1994, vol. 1, pp. 98-123, designadamente nas pp. 102-105. Em todas as manifestações do género hagiográfico, é sobretudo nas Translationes que a influência da clássica laudatio funebris mais se faz sentir. $V d$. Martin Heinzelmann, Translationsberichte und andere Quellen des Reliquienkultes 
foram posteriormente absorvidos pela hagiografia, integrando, assim, alguns dos seus tópicos mais relevantes. Todavia, no género hagiográfico faz-se igualmente notar a influência dos panegíricos. Os Padres da Igreja, sobretudo os gregos, estudiosos da retórica clássica que eram, cultivaram muito este tipo de literatura ${ }^{13}$.

O panegirista está vinculado ao retrato ideal da pessoa que ele pretende descrever. Por conseguinte, oculta ou cala aspectos menos positivos ou mesmo negativos da vida do retratado. $\mathrm{O}$ hagiógrafo podia agir do mesmo modo. Mas isso seria pedagogicamente errado, pois colocaria o seu herói em níveis inatingíveis, o que, por sua vez, desencorajaria os fiéis de qualquer tipo de imitação. Era preferível pôr a nu as deficiências do biografado, sobretudo se estas pertenciam a um período negro da vida do santo anterior à sua conversão. Essa estratégia permitia ainda demonstrar que os biografados eram, afinal, seres humanos como os leitores e com as mesmas limitações. Por mais ideal, por mais inatingível que a imitação de Cristo pudesse parecer, não eram raros os homens e mulheres que logravam aproximar-se desse objectivo. Os leitores das hagiografias deveriam ser convencidos de que a imitação dos seus modelos de vida lhes era acessível e viam-se, assim, induzidos a imitar a Cristo de forma indirecta: através das realizações concretas de pessoas que tiveram força de vontade para o fazer.

Por outro lado, quando os Cristãos começaram a redigir as biografias dos seus santos, não podiam ignorar uma rica tradição clássica de autores como Xenofonte, Cornélio Nepos, Plutarco, Tácito, Suetónio, Diógenes Laércio, Libânio ou os Scriptores Historiae Augustae, nem podiam evitar a influência literária desses mesmos autores.

A nível da abordagem da caracterização do biografado, por exemplo, há fortes afinidades entre a hagiografia e a obra de Plutarco. O biógrafo de Queroneira preocupa-se, por um lado, em descrever o carácter da personalidade em causa e, por outro lado, em retratá-la de forma indirecta através das suas acções, pois é aí que se materializam e se evidenciam as qualidades, boas ou más, do biografado.

(Typologie des sources du moyen âge occidental, 33), Turnhout, 1979, pp. 89-91, onde sintetiza o que expusera em Martin Heinzelmann, "Neue Aspekte der biographischen und hagiographischen Literatur in der lateinischen Welt", Francia 1 (1973) 27-44.

13 Vd. René Aigrain, L'Hagiographie. Ses sources, ses méthodes, son histoire, Poitiers, 1953, o capítulo IV, intitulado "Les Panégyriques", sobretudo a p. 122:

Les panégyriques des Pères de l'Église ne constituent pas nécessairement, dans leur pensée, une hagiographie de forme oratoire, et peuvent être, comme nos oraisons funèbres, consacrés à des personnages que nous dirions non canonisés [...]. Mais la plupart de ces discours $[\ldots]$ sont des éloges de saints et tout spécialement de saints martyrs [...]. 
Assim acontece na hagiografia ${ }^{14}$. O objectivo de Plutarco era essencialmente parenético ${ }^{15}$. Interessava-lhe sobretudo evidenciar a excelência do carácter e dos valores morais dos grandes vultos da Grécia e de Roma, para instigar os seus leitores à imitação dos actos desses paradigmas da cidadania greco-romana. Procurava demonstrar pela descrição de feitos concretos que o nível de excelência preconizado não estava fora do alcance das capacidades humanas.

Ora, a hagiografia visa precisamente os mesmos objectivos, embora os valores almejados sejam completamente opostos, pois em nada estão relacionados com as preocupações deste mundo, mas tão somente com interesses divinos. As vidas de santos conservam o mesmo vigor parenético dos textos de Plutarco e reforçam-no, porque se trata de interesses vitais e eternos, que excedem largamente os da res publica.

Porém, a hagiografia é mais do que uma biografia. Esta incide muito em aspectos de natureza essencialmente historiográfica, ainda que autores clássicos como Cornélio Nepos e Plutarco rejeitem qualquer conotação historiográfica ${ }^{16}$. Aquela propõe um programa moral, no dizer de Leclercq ${ }^{17}$, ou seja, obedece ao reconheci-

14 Quando o hagiógrafo descreve a vida do seu biografado segundo as características de um modelo anterior, aproxima-se do conceito de "vidas paralelas" ainda que de forma inconsciente ou implícita. Um exemplo bem conhecido e estudado é o da influência emulativa da biografia grega de Santo Antão - a referência da ascese oriental por excelência da autoria de Atanásio, vertida para latim por Evágrio, na diegese e caracterização de S. Martinho - o pai da ascese ocidental - por Sulpício Severo. S. Martinho não podia ficar atrás de Santo Antão. Sulpício pretende, deste modo, obter para S. Martinho estatuto idêntico ao que Santo Antão detinha no Oriente, mesmo incorrendo em anacronismos que poderiam pôr em causa a credibilidade de alguns passos da obra. Jacques Fontaine fala da "volonté quasi déclarée, chez Sulpice, de rivaliser étroitement avec Athanase en certains passages, mais au niveau de la comparaison entre les exploits respectifs de Martin et d'Antoine. Cela n'exclut pas davantage l'imitation étroite de certaines phrases, surtout dans «les enfances Martin», où il s'agit bien de suggérer au lecteur l'esprit de ce concours de sainteté". Vd. Sulpice Sévère: Vie de Saint Martin. Tom. I. Introduction, texte et traduction par Jacques Fontaine, Paris, 1967 (Sources Chrétiennes: 133), pp. 60-61, n. 2.

Dieter von der Nahmer apresenta, a propósito dos objectivos plutarquianos, um confronto interessante entre as vidas dos santos e as Vidas Paralelas de Plutarco. Vd. Dieter von der Nahmer, Die lateinische Heiligenvita. Eine Einführung in die lateinische Hagiographie (Das lateinische Mittelalter), Darmstadt, 1994, pp. 61 sq.

16

$V$ d. e. g. a diferenciação estabelecida por Cornélio Nepos: "ne non uitam eius enarrare, sed historiam uidear scribere" (Pelop. 1); ou a afirmação categórica de Plutarco, na vida

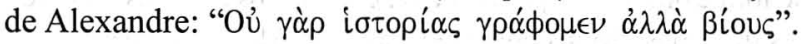

17 Jean Leclercq, L'Amour des Lettres et le Désir de Dieu, Paris, 1990, p. 156. 
mento e levantamento, na vida do biografado, de ideais e qualidades edificantes que caracterizam a personalidade em causa, a qual é, por sua vez, proposta ao leitor como modelo digno de ser imitado.

O confronto valorativo entre a biografia pagã, representada pela biografia histórico-política de natureza épica e pela biografia filosófica, e a de inspiração cristã é bem evidente em Sulpício Severo. No seu prefácio à Vita Sancti Martini Turonensis, compara a motivação do labor redactorial de biógrafos profanos aos objectivos que o movem a ele, autor cristão, a descrever os feitos de S. Martinho. Simultaneamente expõe em que se distingue a finalidade e utilidade das biografias profanas das do tipo cristão, mas não deixa de reconhecer, logo no início, que as primeiras visam objectivos essencialmente educativos:

[...] todavia, [os escritores,] ao proporem aos leitores exemplos de grandes homens, também suscitavam uma emulação nada pequena. Mas esta sua preocupação não tinha qualquer relação com aquela vida bem-aventurada e eterna. [...] que proveito colheu a posteridade com a leitura dos combates de Heitor ou da filosofia de Sócrates, uma vez que não só é estultícia imitá-los, mas também é loucura não os contestar com maior aspereza? Efectivamente, os que avaliam a vida humana apenas pelas acções presentes, confiaram as suas esperanças às fábulas e as suas almas aos sepulcros. Com efeito, eles julgaram que deviam ser perpetuados somente até à memória dos homens quando o dever dos homens é o de alcançar a vida eterna mais do que a memória eterna, não através da escrita ou da luta e da filosofia, mas levando uma vida piedosa, santa e religiosa. E, de facto, este erro humano transmitido pela literatura assumiu tal vigor que encontrou seguramente muitos émulos quer desta vã filosofia, quer daquele louco heroísmo. Daí que, segundo me parece, eu serei útil, se descrever a vida de um santíssimo varão, no intuito de ela servir, depois, a outros de exemplo: é que os seus leitores serão, efectivamente, incitados à verdadeira sapiência, à milícia celeste e à virtude divina. [...] procurámos, todavia, que não ficasse na sombra quem merecia ser imitado ${ }^{18}$.

Vita Sancti Martini Turonensis, 1.2-6:

Quae res utique non perennem quidem, sed aliquantulum tamen conceptae spei fructum afferebat, quia et suam memoriam, licet incassum, propagabant, et, propositis magnorum uirorum exemplis, non is parua aemulatio legentibus excitabatur. Sed tamen nihil ad beatam illam aeternamque uitam haec eorum cura pertinuit. [...] quid posteritas emolumenti tulit legendo Hectorem pugnantem aut Socraten philosophantem? Cum eos non solum imitari stultitia sit, sed non acerrime etiam impugnare dementia: quippe qui humanam uitam praesentibus tantum actibus aestimantes, spes suas fabulis, animas sepulcris dederint. Siquidem ad solam hominum memoriam se perpetuandos crediderunt, cum hominis officium sit, perennem potius uitam quam perennem memoriam quaerere, non scribendo aut pugnando uel philosophando, sed pie 
Como se pode ver, ele condena os objectivos deste género de biografias questionando os seus valores efémeros, que não ultrapassam a barreira da morte, para sublinhar explicitamente a importância catequética e edificante da leitura das biografias cristãs, cuja acção se repercute e se perpetua na vida eterna e pode contribuir, através da aemulatio, para que outros superem igualmente a meta extrema da existência terrena. Convém relembrar que, embora não se trate de uma obra medieval, a Vita Sancti Martini Turonensis foi um dos textos que mais influenciou a produção hagiográfica posterior ${ }^{19}$.

Uma vez que a hagiografia não se confunde com a historiografia e supera os objectivos biográficos da literatura pagã, o retrato dos santos era descrito não de forma meramente biográfica, mas hagiográfica, recorrendo os autores, por isso, a muitos tópicos comuns ao género hagiográfico. Todavia, a influência da biografia clássica na literatura hagiográfica manifesta-se, a nível do conteúdo, na transposição e integração de episódios, anedotas ou motivos veiculados pela literatura clássica. No plano formal, essa influência reflecte-se na adaptação de recursos literários originariamente clássicos.

Um desses exemplos é o da famosa alegoria clássica da nau do Estado, governada pelo timoneiro da Nação que enfrenta o mar encapelado. Como é sabido, foi Alceu um dos primeiros autores a desenvolver esta alegoria na literatura. O próprio poeta de Lesbos foi um dos principais modelos de Horácio. Não admira, pois, que o Venusino retomasse o mesmo tópico numa ode célebre ${ }^{20}$. Quintiliano correlacionava, de forma muito explícita, as vagas e tempestades da versão horaciana da alegoria da nau do Estado com as guerras civis: "fluctuum tempestates pro bellis

sancte religioseque uiuendo. Qui quidem error humanus litteris traditus in tantum ualuit, ut multos plane aemulos uel inanis philosophiae uel stultae illius uirtutis inuenerit. Vnde facturus mihi operae pretium uideor, si uitam sanctissimi uiri, exemplo aliis mox futuram, perscripsero: quo utique ad ueram sapientiam et caelestem militiam diuinamque uirtutem legentes incitabuntur. [...] dedimus tamen operam, ne is lateret qui esset imitandus.

Esta obra de Sulpício Severo serve de charneira entre a biografia clássica pagã e a hagiografia, conforme J. Fontaine sublinha: "la Vita Martini est-elle de ces ouvrages par lesquels un seuil est en quelque sorte franchi dans l'évolution et les mutations successives des genres littéraires; une de ces oeuvres qui, dans un domaine précis, résument tout le passé et annoncent tout l'avenir: en l'occurrence, le passé de la biographie antique et l'avenir de l'hagiographie médiévale". Vd. Sulpice Sévère: Vie de Saint Martin. Tom. I. Introduction, texte et traduction par Jacques Fontaine, Paris, 1967 (Sources Chrétiennes: 133), pp. 62.

Vd. Alceu fr. 326 Lobel-Page e Horácio, Carmina, 1.14. 
ciuilibus" ${ }^{, 21}$. Mas os autores cristãos e medievais logo transpuseram a imagética política para as convulsões do espírito. S. Gregório Magno fá-lo de forma exemplar:

Nos uero quia uidelicet peccatores sumus, ab occidente uobis ligna transmisimus, quae construendis apta nauibus tumultum mentis nostrae signantia in marinis semper fluctibus agitentur ${ }^{22}$.

Hagiógrafos, como Tomás de Celano, retomam:

Illos autem infirmos maiore fouebat clementia patientia supportabat, quos uelut fluctuantes paruulos tentationibus agitatos et spiritu deficientes sciebat ${ }^{23}$.

A literatura cristã e medieval, particularmente a hagiografia, interpretam-na, portanto, não numa perspectiva colectiva, estatal, mas já numa vertente individualizada, personalizada e, ao mesmo tempo, cristianizada. Cada ser humano traça o rumo da sua vida e procura levar o barco a bom porto, a despeito da forte agitação das ondas. Para o cristão, porém, nem tudo, no mar da vida, é bonança. As agitações mundanas fazem alterar a placidez espiritual e tornam o mar encrespado, um mar que encobre diversos perigos. Os escolhos da vida são aqueles que podem atentar contra a salvação do espírito, a verdadeira vida; são os perigos do maligno que assolam a alma e procuram evitar que a barca consiga chegar ao porto de destino, que representa igualmente a paz, pois é onde a alma encontra o seu repouso, no Reino dos Céus.

O débito da hagiografia para com a literatura clássica não se confina aos panegíricos, às orações fúnebres ou à biografia. O género hagiográfico retoma, muitas vezes, os valores e objectivos pragmáticos da épica pagã e confere-lhe uma dimensão transcendente ${ }^{24}$. Enquanto, para o herói homérico, importava sobretudo o

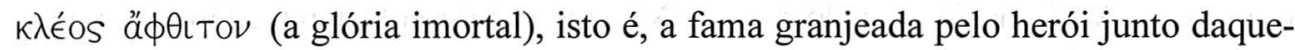

Quintiliano, De Institutione Oratoria, 8.6.44.

S. Gregório Magno, Registrum epistularum (SL 140), lib. 6, epist. 61.

Vd. Tomás de Celano, Vita secunda sancti Francisci, pars 2, par. 177.

24

O santo, particularmente se este for mártir ou confessor, é o novo herói épico e a hagiografia incorpora os valores da epopeia. Vd. Hippolyte Delehaye SJ, Les Passions des martyrs et les genres littéraires (Subsidia hagiographica, 20), Bruxelles, 1966, pp. 171 sqq; Alison Goddard Elliott, "The Martyr as Epic Hero: Prudentius' Peristephanon and the Old French Chanson de Geste", Proceedings of the Patristic, Medieval, and Renaissance Conference, Villanova, 1978, pp. 119-136; Idem, "The Power of Discourse: Martyr's Passion and Old French Epic", Mediaevalia et Humanistica n.s. 11 (1982) 39-60; Idem, Roads to Paradise, Reading the Lives of the Early Saints, Hanover-London, 1987, no capítulo intitulado "Hagiographic Epic" (pp. 16-41). 
les que passarão palavra às gerações futuras, ao herói da nova épica interessam apenas as contas que ele deverá prestar a Deus, no juízo final, pelas suas acções. Pelo contrário, este tudo faz para esconder ou calar os acontecimentos miraculosos que Deus realiza por sua intercessão. É este, por exemplo, um dos motivos aduzidos por Sulpício Severo para justificar o número reduzido, em sua opinião, de prodígios descritos na sua biografia de S. Martinho:

[...] adeo ea, in quibus ipse tantum sibi conscius fuit, nesciuntur, quia laudem ab hominibus non requirens, quantum in ipso fuit, omnes uirtutes suas latere uoluisset ${ }^{25}$.

Neste último caso, são os fiéis, devotos do santo, que se importam com o que se possa dizer do seu herói e se preocupam em imortalizar os seus feitos, de modo a valorizarem os poderes intercessórios do seu santo patrono e, por conseguinte, o prestígio da comunidade que o venera. A hagiografia é, pois, de certo modo, a herdeira de uma antiga épica rebaptizada pela pragmática cristã. Se, na epopeia profana, prevalece a gesta heróica alcançada pela acção das armas, a hagiografia preconiza o silêncio das armas e enaltece os promotores da paz evangélica. Esse facto é bem evidente na forma como Sulpício Severo descreve, na sua Vita Sancti Martini Turonensis o episódio da partilha da capa: "Arrepto itaque ferro, quo accinctus erat, mediam diuidit partemque eius pauperi tribuit, reliqua rursus induitur" (Vita Sancti Martini Turonensis, 3.2). Ora, esta expressão faz lembrar Virgílio (Aeneis 9.750 sq: "mediam ferro ... frontem diuidit"). À brutalidade e violência da acção em Virgílio opõe-se o gesto pacífico e caridoso de S. Martinho. O soldado de Cristo transforma-se, assim, no anti-herói, que utiliza a espada não para matar, mas para socorrer o próximo. A atitude do soldado romano Martinho representa a evolução de um paradigma de valores para uma nova concepção de herói: o que pratica as virtudes cristãs no seu grau mais heróico. O heroísmo deixou de ser identificado com a militia saeculi e passou a sê-lo com a militia Christi.

Mas é sobretudo em episódios caracteristicamente etiológicos, relacionados com a fundação de templos, determinados costumes, com o aparecimento de imagens, com um culto específico ou qualquer outro aspecto do fenómeno religioso, que a hagiografia e a literatura clássica revelam semelhanças. Os ícones ou estátuas que

Vita Sancti Martini Turonensis, 1.7:

[...] assim, desconhecem-se os factos de que só ele próprio foi testemunha, porque, como ele não procurava o louvor dos homens, quis, tanto quanto lhe foi possível, esconder todas as suas virtudes. 
surgem do nada, que caem do céu ou são encontrados no interior de árvores e de animais, por meio de revelações em sonhos ou visões ou que são descobertas por acaso em nada ficam atrás da imagem de Palas Atena, do Paládio de Tróia ou da estátua original de Ártemis que Orestes e Ifigénia trouxeram do país dos Tauros, cuja posse era reclamada por muitas localidades da Grécia, Ásia Menor e Magna Grécia.

Suetónio relata, na vida de Augusto, o caso maravilhoso do jovem Octávio que manda calar as rãs que coaxavam junto à casa de campo de seu avô. Desde então, acrescenta o historiador, nunca mais se ouviu o coaxar das rãs naquele lugar. Não nos faz este episódio lembrar um outro da vida de Santo António, que, aliás, também ocorre nas vidas de outros santos ${ }^{26}$ ?

É, todavia, difícil dizer se, neste ou naquele texto, há uma influência directa, indirecta ou se foi fruto do acaso. Intencional, porque inserida na política da cristianização das lendas e costumes dos povos evangelizados, é a sobreposição de elementos cristãos aos pagãos e a substituição de tradições e cultos pagãos por outros cristãos equivalentes ou idênticos, conforme veremos mais adiante.

Entre as diversas finalidades atribuíveis ao género hagiográfico cabe a primazia ao pragmatismo catequético e à edificação. A principal finalidade da hagiografia era, efectivamente, didáctica: visava propósitos essencialmente catequéticos, fornecendo ao leitor um modelo de vida digno de ser imitado, de forma a que a obra pudesse contribuir para a santificação, para a edificação espiritual do cristão. E é certo que muitos se converteram ou professaram votos religiosos sob influência directa da leitura das vidas dos santos ${ }^{27}$. Daí que o retrato moral do santo consubstanciasse, de forma muito concreta, o ideal evangélico, pois tratava-se de uma de muitas formas de imitar a Cristo. A forma suprema da imitatio Christi era o martírio, o Baptismo de sangue. Os primeiros santos foram efectivamente os mártires e os confessores.

Associada à preocupação didáctica e catequética surge depois a propaganda cristã e a polémica antipagã. A hagiografia serviu, ao longo dos séculos, estes dois propósitos de natureza predominantemente apologética: inicialmente, durante a fase de crescimento, de afirmação e de expansão do Cristianismo, enquanto conviviam lado a lado os dois tipos de religião, procurando o Cristianismo suplantar e abafar as festas, os rituais e os mitos pagãos. Caso paradigmático é o da calendarização da festa da Natividade de Cristo a 25 de Dezembro, festa do Sol e do império, mas

26 Sobre estes e muitos outros exemplos, vd. Hippolyte Delehaye S.J., Les légendes hagiographiques, Bruxelles, ${ }^{2} 1906$, pp. 30-41 e demais bibliografia aí mencionada.

27 Um dos exemplos mais conhecidos é o de Santo Inácio de Loyola. 
poderíamos acrescentar a substituição, após o Édito de Milão (em 313), de outras festas populares pagãs pelas celebrações dos santos, ou a substituição dos mitos pagãos pelas lendas hagiográficas ${ }^{28}$. O paralelismo entre a lenda de S. Jorge, por um lado, e a figura de Hércules ou os mitos de Perseu e de Teseu, por outro, permite que este santo ocupe o lugar dos heróis gregos nos espaços cultuais que lhes eram dedicados. De resto S. Jorge (Georgios) substitui igualmente Deméter, a deusa da agricultura, tal como a similitude do antropónimo permite que S. Demétrio ocupe o lugar da mesma deusa como orago da igreja onde antes existia um templo em honra da divindade pagã. À história de Édipo, por exemplo, sobrepõe-se a biografia de S. Julião, o hospitaleiro, ou a história de Santo Aleixo, que, aliás, também apresenta muitos pontos de contacto com os episódios do regresso de Ulisses ao lar.

Lembremos que, do ponto de vista hagiológico, o culto dos santos na sociedade cristã era muito idêntico ao culto dos heróis na Antiguidade Clássica. De resto, o estatuto de uns e outros eram semelhantes, pois, embora fossem superiores aos restantes mortais, não eram deuses ${ }^{29}$. Como Walter Burkert bem define, "nenhum deus é herói; nenhum herói se transforma em deus", embora ambos, deuses e heróis, constituam a esfera do sagrado ${ }^{30}$. Como o seu poder é imortal, o herói continua, já depois da morte, a exercer a sua influência no local do túmulo. Santos e heróis estavam, assim, ligados a locais de culto, à protecção das cidades às quais se encontravam associados fosse pelo nascimento, fosse pela morte, fosse pelos seus milagres e feitos heróicos, respectivamente. Cada povoação tinha o seu santo ou herói. Sobre o túmulo destes, erguia-se um templo. Se uma cidade não possuísse as relíquias de qualquer santo, recorria à sua importação através da translatio. Mas já assim haviam feito os Atenienses, conforme relata Plutarco na vida de Teseu, quando transferiram solenemente para a sua cidade os restos mortais de Teseu. A apresentação das chamadas relíquias secundárias - objectos que pertenciam ao santo - também já existia na Antiguidade.

Os paralelismos entre o culto dos santos e o dos heróis não passaram despercebidos aos Antigos. A investigação actual fala de "semelhança estrutural"31. As

Por sua vez, a hagiografia podia influenciar, ainda que de forma involuntária, a formação de lendas pagãs. Na figura de Fausto podem identificar-se fortes analogias com a personalidade de S. Cipriano de Antioquia.

Uma das poucas diferenças entre um e outro residia no poder. O poder do herói era-lhe inato, enquanto o poder do santo era-lhe concedido por Deus.

Vd. W. Burkert, Griechische Religion der archaischen und klassischen Epoche, Stuttgart-Zürich, 1977, p. 315.

31

Id., ibid., p. 318. 
analogias são, efectivamente, muitas. Pese embora esta forte semelhança entre duas realidades tão diferentes, não podemos dizer que o culto dos santos seja uma evolução do culto dos heróis. Além de se integrar na tradição judaica da veneração dos patriarcas e dos profetas junto dos respectivos túmulos, o culto dos santos provém efectivamente do culto dos mártires. Como salienta Delehaye, as analogias entre os dois tipos de culto são fruto do mesmo estado de espírito em circunstâncias similares $^{32}$. Mas houve um aproveitamento por parte do Cristianismo de muitos aspectos relacionados com o culto pagão.

À propaganda antipagã segue-se, já pela Idade Média adentro, o aproveitamento da hagiografia na apologética e no combate dogmático e doutrinário contra as diversas correntes hereges, e, posteriormente, no âmbito da Reforma e da Contra-reforma, contra os grupos dissidentes protestantes.

As finalidades literárias da hagiografia são, muitas vezes, contaminadas por tendências externas relacionadas com intuitos políticos ou proveitos económicos. Esse aproveitamento político começou desde muito cedo. Por exemplo, a actividade hagiográfica promovida pelo Papa Dâmaso (séc. IV) - que redigiu e mandou gravar nas sepulturas do mártires muitos elogios fúnebres em versos latinos, aliás, inspirados em Lucrécio e Virgílio -, aliada ao culto prestado aos mártires romanos tinha objectivos claramente políticos, pois visava conferir maior autoridade espiritual à cidade eterna por oposição à nova capital do Império que possuía a residência do poder político desde o ano de 325: Constantinopla ${ }^{33}$.

Vd. Hippolyte Delehaye S.J., Les légendes hagiographiques, Bruxelles, ${ }^{2} 1906$, p. 189.

Como esta cidade não tinha relíquias de mártires, passou a importá-las. O fenómeno da translatio ter-se-ia iniciado nessa época. Vd. Kenneth L. Woodward, Making Saints, London, 1996, p. 63. A presença de relíquias ocasionava o surgimento de literatura hagiográfica: se não eramVitae, eram, pelo menos, Translationes. Quanto a posse de relíquias de santos populares contribuía para o prestígio da diocese local demonstra-o o caso das relíquias dos principes Apostolorum, S. Pedro e S. Paulo, no séc. VI. O imperador bizantino Maurício recorreu à diplomacia de sua esposa, a imperatriz Constantina, para impetrar do Pontífice Romano, Gregório Magno, algumas das relíquias dos príncipes dos Apóstolos. Apesar de Bizâncio já possuir as relíquias de Santo André, irmão de S. Pedro, estas não tinham o mesmo peso que as de qualquer um dos outros dois santos. Gregório Magno, porém, aquando de uma longa estadia em Constantinopla, conhecera bem a diplomacia da corte bizantina e, numa carta endereçada à imperatriz, soube esquivar-se a este pedido, preservando, assim, o prestígio ímpar da velha metrópole e a popularidade universal (católica e ecuménica, nos respectivos sentidos etimológicos) granjeada já a partir do séc. IV com as inúmeras peregrinações (ROMArias) provenientes dos diversos quadrantes da Cristandade. Vd. Epistula 4.30, in Gregorii I Papae Registrum Epistolarum. Ed. P. Ewald. Berlin, 1891 (MGH, Epist. 1.1). 
Este aproveitamento político dos vectores hagiológicos na luta pela supremacia eclesiástica entre diferentes poderes religiosos também se manifesta em círculos mais restritos.

A preocupação em canonizar os fundadores ou os reformadores de dioceses, igrejas, mosteiros e congregações visava obter uma sanção divina da própria instituição e, consequentemente, o reconhecimento católico, i. e. universal, da importância dessa comunidade. Por outro lado, o santo servia de intercessor, de protector, de patrono da instituição e dos seus membros.

Tomando em consideração os conflitos relativos à posse de terrenos, de outros bens materiais, de rendas e de prebendas entre a nobreza e o clero, por um lado, e o clero entre si (designadamente entre bispos e abades), por outro lado, podemos divisar objectivos menos nobres e mais materialistas no seio de algumas hagiografias. Aliás, a reivindicação de direitos territoriais era uma das principais causas da falsificação de documentos na Idade Média. Que testemunho poderia servir melhor as causas das disputas territoriais do que a hagiografia? Foi essa uma das finalidades que, no séc. VI, presidiu à redacção de uma Vita de $\mathrm{S}$. Tudualdo, bispo de Tréguier.

Paralelamente, a hagiografia podia igualmente contribuir para dirimir conflitos entre o clero secular e o religioso, designadamente no que diz respeito à defesa dos direitos monásticos, como é o caso da Vita de Santo Egídio da Occitânia, redigida no séc. X, cuja finalidade consiste em combater as pretensões dos bispos de Nîmes.

Em alguns casos, a hagiografia fixava a relação de forças entre a posição dos bispos e dos soberanos, em consequência do relacionamento difícil e, por vezes, conflituoso entre o poder régio e o eclesiástico ${ }^{34}$.

A hagiografia de santos monásticos era imediatamente promovida pelas ordens religiosas às quais os santos pertenciam. De um modo geral, o principal santo de cada uma dessas ordens era o respectivo fundador.

Tal como para as ordens religiosas era importante que alguns dos confrades, e muito particularmente o seu fundador, fossem elevados às honras dos altares, também as famílias reais e as linhagens mais nobres ansiavam por um santo entre os seus membros. Os motivos eram os mesmos. No caso das ordens religiosas, era uma confirmação divina da importância da ordem religiosa em causa. Quanto à realeza e à aristocracia, em geral, o reconhecimento oficial da santidade de um dos seus

Um dos casos mais ilustrativos é o da vida de S. Remígio por Hincmaro de Reims. 
membros era interpretada como uma confirmação divina do êxito político da linhagem, salientando-se ainda uma crença inabalável na transmissão hereditária do carisma de santidade. Neste último grupo, desempenha um papel importante a realeza. É neste sentido que se fala de "santidade real, dinástica ou familiar". Todavia, convém não confundir "santidade real" com "realeza sagrada", embora haja uma correspondência directa entre a força carismática da monarquia, cujo poder provinha directamente de Deus, desde a unção do rei David, e a posse de faculdades e de virtudes exemplares ${ }^{35}$. Como salienta Lauwers, não é a função, mas sim a pessoa que faz o santo ${ }^{36}$. Já as biografias clássicas distinguịam a nobreza de linhagem da nobreza de carácter e desde S. Jerónimo prevalece o princípio enunciado por este doutor da Igreja: "nobilis genere, sed nobilior sanctitate". Para o ser humano, a santidade tem prioridade sobre a nobreza, e os reis canonizados têm perfeita consciência desse facto.

Antes de haver santos dinásticos, as linhagens reais tomavam para si outros santos como patronos no intuito de garantirem a protecção divina e o sucesso político. No entanto, o dever de entreajuda que obrigava mutuamente os familiares na Idade Média perpetuava-se do mesmo modo na esfera celeste. Na mentalidade medieval, os santos dinásticos tinham obrigações morais para com os seus familiares que ainda estavam na Terra. Assim se compreende, por exemplo, que o Infante D. Henrique, convicto da santidade de seu irmão mártir, instituiu D. Fernando orago do altar adjacente ao túmulo henriquino na Batalha.

Assim como os mártires foram os primeiros santos a serem canonicamente reconhecidos como tais, também os primeiros reis a ascenderem aos altares foram, desde o séc. VI, os santos reis mártires ${ }^{37}$, seguindo-se-lhes, desde o séc. IX, os santos reis confessores ${ }^{38}$.

Cf. Arnold Angenendt, Heilige und Reliquien. Die Geschichte ihres Kultes vom frühen Christentum bis zur Gegenwart, München, 1994, p. 100; Idem, "Rex et Sacerdos. Zur Genese der Königssalbung", Tradition als historische Kraft. Interdisziplinäre Forschungen zur Geschichte des früheren Mittelalters. Festschrift Karl Hauck, edd. Norbert Kamp, Joachim Wollasch, Berlin-New York, 1982, pp. 100-118.

$V d$. Michel Lauwers, "Sainteté royale et sainteté féminine dans l'Occident médiéval", Revue d'histoire ecclésiastique 83,1 (1988) 58-69, na p. 59.

Cf. e. g. S. Segismundo ( $† 523)$, Rei da Borgonha e fundador do Mosteiro de S. Maurício de Agaune (Valais); Santo Edmundo ( $†$ 839), Rei da Ânglia Oriental; S. Venceslau da Boémia ( $†$ 929); Santo Olavo da Noruega $(\dagger 1030)$, etc.

Vd. R. Folz, Les säints rois du moyen âge en Occident (VI ${ }^{e}$-XIII ${ }^{e}$ s.) (Subsidia Hagiographica, 68), Bruxelles, 1984, pp. 23-67. 
Sobretudo durante o período da cristianização da Europa, mereciam especial relevância os imperadores e reis que se convertiam e se deixavam baptizar (ou os prelados e missionários que os convertiam). Tratava-se de personalidades que serviam de charneira entre duas fases distintas da História de uma nação: era o primeiro príncipe cristão de uma linhagem que se perpetuava ao longo da Idade Média.

Também convinha que o principal santo dinástico fosse o fundador de uma dinastia, de uma nação. Esta preocupação não era apenas exclusiva da Idade Média. Nós conhecemos entre nós uma tentativa de canonização de D. Afonso Henriques, sustentada pela lenda do milagre de Ourique, que foi posteriormente recuperada pelo cronista de Santa Cruz Fr. Nicolau de Santa Maria e sobretudo por Fr. Bernardo de Brito, cronista de Alcobaça, numa fase crítica da nossa História ${ }^{39}$. Numa época em que Portugal necessitava de afirmar a sua independência, assistimos a uma clara subordinação - para não dizer falsificação - do fenómeno religioso à estratégia política.

Do período filipino e pós-filipino, já numa fase em que a Restauração da independência ia de par com a recuperação do prestígio da nação fidelíssima, data a actividade de Jorge Cardoso com o Officio menor dos Sanctos de Portugal (1637) e o Agiológio Lusitano dos Sanctos, e Varoens illustres em virtude do Reino de Portugal e suas conquistas (1652-1744). Este e outros autores procuram legitimar a dinastia e, consequentemente, a independência de Portugal ao recuperarem a santidade dinástica e a noção de beata stirps através do elenco de todos os santos portugueses, incluindo aqueles que, pela sua ligação ao nosso território, eram anteriores à nacionalidade.

A noção de santo dinástico levou, na Idade Média, as casas reais europeias a fazerem desde logo o levantamento dos santos presentes nas genealogias reais. Só a casa de Andessa contava 27 santos entre os seus membros ${ }^{40}$ !

Embora a canonização de Carlos Magno, o fundador de um novo império, tenha interpretações políticas, conforme veremos mais adiante, a linhagem carolíngia contava entre os seus membros com alguns santos ou personalidades com fama de santidade e que eram veneradas como tais sobretudo a partir do séc. XI: Arnulfo de

Sobre a uexata quaestio do milagre de Ourique, $v d$. Ana Isabel Carvalhão Buescu, $O$ Milagre de Ourique e a História de Portugal de Alexandre Herculano. Uma Polémica Oitocentista, Lisboa, 1987. Quanto à canonização do nosso primeiro Rei, vd. I. da Costa Brochado, "Tentativas de canonização de el-rei D. Afonso Henriques", Anais da Academia Portuguesa da História II Série, 8 (1953) 307-337.

Vd. Arnold Angenendt, Heilige und Reliquien. Die Geschichte ihres Kultes vom frühen Christentum bis zur Gegenwart, München, 1994, p. 100. 
Metz, Ita e suas filhas Gertrudes de Nivelle e Bega de Andenne, Gúdula de Bruxelas e sua irmã Reinalda (ambas sobrinhas de Gertrudes de Nivelle), Reinilde e ainda muitos outros, que não alcançaram o reconhecimento oficial da heroicidade das suas virtudes. A presença de santos entre os antepassados reais conferia à linhagem a categoria de beata stirps. A hagiografia merovíngia insistia particularmente na ascendência nobre dos biografados, contribuindo assim para uma valorização de um ideal de santidade aristocrático. Daí a noção de santos nobres ${ }^{41}$.

Recorrendo à linguagem de Rosvita de Gandersheim, Karl Hauck salienta que "tal como a eleição de um rei transmite as dignidades reais não apenas à sua própria pessoa, mas a toda a linhagem, a qual se vê, assim, transformada em ueneranda stirps, também toda a linhagem é santificada através de um rei santo, toda a linhagem se torna uma beata stirps e o seu sangue é o germen sanctorum auorum,42. Como A. Vauchez refere, as tradições do paganismo germânico, mas também a mentalidade da Antiguidade tardia partilhavam da conviç̧ão "de que a perfeição moral e espiritual dificilmente se podia desenvolver fora de uma linhagem ilustre"43.

As hagiografias não deixavam de fazer referência a essa santidade régia familiar, ora de modo muito ténue, sob a forma de santos venerados pelo biografado ${ }^{44}$, ora de modo muito explícito, no enquadramento genealógico do biografado ${ }^{45}$.

Sabemos, aliás, quão importantes eram as genealogias régias na Idade Média. As diversas dinastias deviam legitimar a sua linhagem desde tempos quase imemoriais. À imitação do que o Evangelista S. Mateus faz com Cristo, desen-

41 Vd. Arnold Angenendt, Geschichte der Religiösität im Mittelalter, Darmstadt, 1997, pp. 342 sqq, Arnold Angenendt, Heilige und Reliquien. Die Geschichte ihres Kultes vom frühen Christentum bis zur Gegenwart, München, 1994, pp. 99 sqq, Martin Heinzelmann, “Adelsheiliger”, Lexikon des Mittelalters, vol. 1 (1980), col. 148 e demais bibliografia aí citada.

42 Vd. Karl Hauck, "Geblütsheiligkeit”, Liber Floridus. Mittellateinische Studien Paul Lehmann zum 65. Geburtstag ... gewidmet (edd. B. Bischoff e S. Brechter), St. Ottilien, 1950, pp. 187-240, especialmente pp. 190-191.

43 Vd. André Vauchez, "O Santo", O Homem Medieval (ed. Jacques Le Goff \& alii), Direcção de Jacques Le Goff, Lisboa, 1989, pp. 211-230, designadamente p. 215.

44 D. Fernando, o Infante Santo, por exemplo, tinha uma especial devoção por Santo Eduardo o Confessor, Rei da Inglaterra, e S. Luís IX, Rei de França, seus antepassados. Frei João Álvares refere-o e o hagiógrafo latino não deixou de aproveitar essa referência.

O Liber de sanctitate meritorum et gloria miraculorum beati Karoli Magni, uma obra hagiográfica em honra de Carlos Magno, começa justamente assim: Santus igitur Arnulfus ... genuit ... 
volvendo a sua ascendência desde Abraão e radicando a linhagem do Salvador na dignidade régia de David, também os reis medievais procuram justificar a sucessão régia desde o primeiro ungido do Senhor. Alguns vão até mais longe e conseguem fazer remontar a linha sucessória até Noé, o eleito divino, do qual descende toda a raça humana. Aliás, muitas das crónicas medievais começam logo por aí, e os livros de linhagem inserem-se nessa tradição. Noutros casos, os cronistas fazem derivar as casas reais de figuras ancestrais da história troiana, da romana ou dos próprios deuses greco-romanos ${ }^{46}$. Na Idade Média, as principais genealogias recuavam até Carlos Magno donde remetiam para os antigos imperadores romanos e para os Troianos, até chegarem a Noé.

A partir de certo momento, houve uma evolução quantitativa e qualitativa no reconhecimento da heroicidade da prática de todas as virtudes relativamente a personagens régias. Na verdade, com a canonização de nove reis (só no séc. XII), são propostos à realeza europeia novos modelos de santidade. Alguns desses reis e imperadores são dos santos que mais prestigiam algumas das casas reais europeias, e. g. Santo Henrique II, imperador do Sacro Império (1141) ou Santo Eduardo, o Confessor, rei de Inglaterra (1161) ${ }^{47}$. A partir do séc. XIII aumenta a quantidade de santos pertencentes às famílias reais da Europa, sobretudo às das mais antigas nações. Todavia, algumas dessas canonizações só ocorreram após o concílio de Trento certamente para incentivar as comunidades católicas que se conservaram

Os Francos fazem remontar a sua dinastia aos Troianos. Outros povos seguem o seu exemplo. $V d$. Frantisek Graus, "Troja und trojanische Herkunftssage im Mittelalter", Kontinuität und Transformation der Antike im Mittelalter (Veröffentlichung der Kongressakten zum Freiburger symposion des Mediävistenverbandes), ed. Willi Erzgräber, Sigmaringen, 1989, pp. 25-43, sobretudo pp. 32 sqq. Os Bávaros consideram-se descendentes de Noé e, por via de uma outra linhagem, de Hércules. Os Germânicos provinham do Gigante Teutão (donde provém o adjectivo "teutónico"). Todavia, enquanto Eneias chegou às praias de Itália, Príamo desembarcou nas margens do Reno. Aí as suas gentes tomaram as mulheres teutónicas por esposas. Desde então, Eneias passou a dar aos novos descendentes de Príamo o nome de Germanos (Germani). Cf. ainda K. Kraft, Zur Entstehung des Namens Germania, Wiesbaden, 1970, e A. A. Lund, "Entstehung und Geschichte des Namens und Begriffs Germani", Aufstieg und Niedergang der römischen Welt II.33.3 (1991): 1858-1988.

Santo Eduardo seria o rei dinástico que iria nobilitar as dinastias inglesas. $V d$. André Vauchez, "O Santo", O Homem Medieval (ed. Jacques Le Goff \& alii), Direcção de Jacques Le Goff, Lisboa, 1989, pp. 211-230, designadamente p. 217:

Em Inglaterra, o culto do rei anglo-saxão Eduardo o Confessor (morto em 1066) assumiu dimensões nacionais a partir do século XII, quando os Plantagenetas, à semelhança do que se passava em França, tentaram implantar a ideia de uma realeza sagrada e taumaturga. 
fiéis em zonas da reforma protestante ${ }^{48}$

Por outro lado, não é de admirar que, na Idade Média, mais de $40 \%$ dos santos provenham das camadas mais elevadas da sociedade, uma vez que a maioria dos bispos e dos abades também provinha da aristocracia. Muitos deles eram filhos de reis. Sobretudo aos filhos bastardos estava reservada uma carreira eclesiástica.

Se, no caso dos lugares mais elevados na hierarquia do clero secular, os santos eram oriundos das classes mais elevadas da sociedade, os santos das ordens monásticas eram provenientes das classes mais baixas. Por outro lado, enquanto os santos monásticos eram de características mais rurais e se notabilizavam sobretudo pela vivência de uma piedade cristã geograficamente muito limitada, os das ordens mendicantes eram, como diz M. Goodich, "um produto característico da sociedade urbana, activos na campanha por uma reforma social, na guerra contra a heresia, na missão, em acções sócio-caritativas, na educação e nas cruzadas" e facilmente eram instrumentalizados, servindo os interesses da política papal"49.

Tão ou mais importante do que a hagiografia para reforçar as pretensões políticas e, por conseguinte, o prestígio de uma comunidade civil ou religiosa - igreja, mosteiro, diocese, nação... - era a localização do túmulo do santo ou a posse das suas relíquias.

O local é, a par da data e da lenda, uma das principais coordenadas hagiográficas fixadas por Delehaye e que passaram a servir de referência no domínio dos estudos hagiológicos. A presença das relíquias do santo não só reforçava o poder da igreja local, como contribuía, enquanto pólo de atracção de doações e de peregrinos e, por conseguinte, de um turismo religioso rudimentar, para o desenvolvimento económico não apenas da comunidade, mas também da região.

O corpo do santo era penhor da sua presença protectora e o exemplo do santo, sobretudo se este fosse mártir, fortalecia e encorajava a comunidade. Em alguns casos, os exércitos levavam para as campanhas militares as relíquias ou as imagens dos santos, de forma a assegurarem, no campo de batalha, a presença protectora desses intercessores. A importância que era atribuída às relíquias está, de certo modo, no mesmo plano de lendas exploradas pela literatura antiga como a do Velo

48 49

É esse o caso de Eduardo o Confessor, Rei da Inglaterra ( $† 1066)$, cuja canonização foi formalizada em 1680, ou de Henrique II da Alemanha ( $\dagger$ 1024), canonizado em 1632, e de muitos outros.

Vd. Michael Goodich, Vita Perfecta: the Ideal of Sainthood in the thirteenth Century, Stuttgart, 1982, p. 172. 
de Ouro ou a do Graal, cuja posse assegurava uma felicidade perpétua, quase paradisíaca, resultante da fertilidade dos campos, do progresso económico, da paz e da saúde. O patronato celeste estendia a sua bênção e protecção sobre a cidade e os peregrinos que visitavam o seu túmulo ou as suas relíquias.

Os Cristãos sempre entenderam que os santos, na presença de Deus, não se esqueciam dos que ainda penavam neste vale de lágrimas. Os santos podiam servir de mediadores entre o Céu e a Terra, entre Deus e os Homens que solicitassem a sua intercessão. Ora, o principal local de culto a um santo era o seu túmulo. O Céu e a Terra tocavam-se onde houvesse veneração de relíquias. A presença destas suscitava peregrinações, imprimindo, por sua vez, o impulso necessário à construção de templos, de forma a permitir uma veneração condigna do padroeiro local.

O número de milagres ocorridos post mortem junto do túmulo do santo ou através da presença das suas relíquias permitia avaliar a santidade da pessoa em causa $^{50}$. Além de a recolha destes milagres ser exigida pelo processo de canonização, ela integrava as hagiografias no intuito de certificar a natureza hierática do conteúdo narrado, justificando, assim, o género literário em que se integrava.

A simples posse das relíquias de um santo era motivo suficiente para provocar alterações no mapa político. O caso mais típico é o de Veneza. A posse das relíquias de S. Marcos, a partir do séc. IX, permite que Veneza consolide gradualmente a sua autonomia política e religiosa.

A interferência do poder civil nas questões religiosas verificava-se na Idade Média sobretudo nos conflitos directos entre as mais elevadas personalidades da hierarquia da Igreja e os reis ou imperadores. No séc. XI, assistimos a uma das maiores crises entre o Vigário de Cristo e o Imperador do Sacro Império romano-germânico. Muito concretamente, estão aqui em causa o Papa Gregório VII, uma personalidade com vasta experiência política, que havia sido o braço direito de nove Pontífices antes de ele próprio ser aclamado sucessor de S. Pedro, e o Imperador Henrique IV. Gregório VII conseguiu robustecer o papado conduzindo-o a um prestígio então impensável, pugnando com firmeza contra as investiduras leigas. Os bispos e abades eram autênticos senhores feudais, com poder absoluto sobre vastos domínios territoriais, aos quais, muitas vezes, apenas interessava o usufruto das rendas e bens eclesiásticos. Gregório VII quis libertar os cargos eclesiásticos dos interesses materiais e da respectiva sujeição e subserviência ao poder temporal, a fim de que os representantes da Igreja pudessem concentrar a sua aç̧ão nos bens espirituais. Por isso, proibiu, sob pena de excomunhão, tanto a aceitação como a outorga de investiduras eclesiásticas. Aos reis e imperadores, por seu lado, convinha-lhes con- 
servar o direito de investidura de forma a manterem a sua influência e, consequentemente, os seus rendimentos. O imperador Henrique IV contraria o Papa nomeando um bispo (o de Milão). Gregório VII admoesta-o. Henrique IV não faz caso e convoca um concílio. Não resta a Gregório VII outra solução senão excomungá-lo, dispensando os súbditos do juramento de fidelidade ao imperador. Os inimigos de Henrique IV aproveitam para se revoltarem. Na iminência de perder o império, Henrique IV pede a absolvição. O Papa concede-lha. Mas Henrique IV volta atrás com a palavra e insurge-se contra o Papa, que novamente o excomunga. Segue-se uma guerra civil na Alemanha. O imperador deposto nomeia um anti-papa, apodera-se de Roma obrigando Gregório VII a fugir para o exílio, onde morreu, no ano de 1085. Não obstante o papel relevante e determinante desempenhado numa fase tão crítica da História da Igreja, Gregório VII só foi canonizado em 1606.

Sobre esta personalidade política, que foi um dos grandes vultos da Igreja católica, possuímos uma Vita Gregorii VII de um autor alemão, Paul von Bernried, contemporâneo do filho de Henrique IV. Contrariamente ao que seria de esperar, Henrique $\mathrm{V}$ prossegue as reivindicações de seu pai não prescindindo do direito de investidura. A História repete-se, o Papa não cede e Henrique V manda-o prender.

É, pois, neste contexto que é redigida a biografia de Gregório VII. O próprio Paul von Bernried tinha sido perseguido por Henrique V e seus sequazes. Este facto levanta algumas interrogações quanto ao verdadeiro objectivo desta Vita. Parece pouco provável que o autor com a sua obra pretendesse obter a canonização de Gregório VII, cujo nome só passou a figurar no Martirológio Romano a partir de 1584. Intrigante é ainda o facto de ser um alemão e não um italiano a tomar a iniciativa da redacção do texto.

Embora o autor faça referência a alguns milagres, sentimos a falta do habitual catálogo de virtudes. Por outro lado, Paul von Bernied manifesta, de forma muito subjectiva, toda a sua repugnância e animosidade contra Henrique IV, que ele invectiva, chamando-o de modernus Nero. Epítetos semelhantes merecem os opositores do Papa Gregório, alguns dos quais bispos agarrados ao poder e respectivas benesses temporais: iniquus ille Iudas ou perditionis filius et Antichristi minister, ante mundi constitutionem damnatus ${ }^{51}$. E o autor aproveita para reforçar a sua apologia

50 A relação directa entre o número de milagres e a santidade já havia sido estabelecida por Santo Agostinho. Sobre toda esta questão, $v d$. Kenneth L. Woodward, Making Saints, London, 1996, p. 62.

Vd. Acta Sanctorum, Maii, 6. 
em favor do pontificado de Gregório VII transcrevendo documentação variada, desde cartas do próprio Papa Gregório a actas dos sínodos romanos. Esta preocupação em documentar as afirmações com elementos hauridos de arquivos já era clássica - e é sobretudo perceptível na organização da obra de Suetónio-, mas a conjugação de todos estes elementos deixa entrever que não foi uma preocupação de características puramente hagiográficas que esteve na génese desta obra.

A descrição de alguns factos milagrosos coloca Gregório VII nas esferas da santidade. Este reconhecimento divino implícito da rectidão da política do Pontífice retratado aumenta ipso facto o fosso que o separa de Henrique IV, o modernus Nero, o qual é, assim, destituído de qualquer razão nas suas pretensões. Se assim era, também a seu filho, Henrique V, que enveredava pelo mesmo trilho do pai, na altura em que esta Vita estava a ser redigida, não assistia qualquer razão nessa contenda. Os contrastes no retrato de Gregório VII, por um lado, e de Henrique IV e seus parceiros, por outro, eram de tal forma acentuados que não deixavam margem para dúvidas: a obra havia sido redigida com intentos políticos. Embora se reportasse a épocas passadas, a biografia podia ser contextualizada no presente de então, uma vez que a situação histórica se repetia, ainda que com outros protagonistas, os quais não deixavam de estar histórica e pessoalmente relacionados com as personagens anteriores. Todas as críticas aí proferidas, todas as invectivas tinham plena validade na situação presente.

O fundador do Sacro Império romano-germânico, Carlos Magno, foi objecto de diversos tratamentos literários: da épica, como os Gesta Caroli Magni metrica do anónimo Poeta Saxão ${ }^{52}$, à historiografia, como o De Gestis Caroli Magni do anónimo "Monachus Sangallensis", ao pranto ou lamentações, como o Planctus de obitu Karoli $^{53}$. Sobre Carlos Magno possuímos ainda uma biografia: a Vita Karoli Magni de Eginardo. Trata-se de uma biografia stricto sensu. É a primeira vez que se aplica o termo de Vita, que, na Idade Média, estava reservado ao género hagiográfico, a uma obra puramente historiográfica. Como afirma Brunhölzl, “[...] essayer de saisir d'emblée une personalité séculière dans sa vie et ses oeuvres, de la présenter historiquement sans aucune intention religieuse ou spirituelle, équivaut à une nouvelle découverte, car,

52 É uma obra constituída por cinco livros. Aos primeiros quatro livros, redigidos em hexâmetros, dá o autor o nome de Annales de Gestis Caroli Magni imperatoris. O quinto livro trata de uita et obitu Caroli Magni.

53 O pranto ou lamentações é um sub-género literário de influência clássica ( $c f$. os trenos de Simónides) ou bíblica ( $c f$. as Lamentações de Jeremias) e tem afinidades com a elegia e com o elogio fúnebre). 
depuis des siècles, aucune biographie n'avait vu le jour et la biographie antique était oubliée" $"$. Eginardo, um dos protagonistas do chamado Renascimento Carolíngio, recupera para a posteridade a biografia clássica através do exemplo de Suetónio que lhe serviu de modelo na redacção desta obra ${ }^{55}$. A Vita Karoli Magni é uma imitação da suetónica biografia de Augusto, mas é uma imitação que preserva toda a liberdade estilística do seu autor e que, por isso, está longe de algum servilismo que caracterizava algumas imitações medievais na Alta Idade Média.

Há, porém, uma obra de um clérigo de Aquisgrano (Aachen ou Aix-la-Chapelle), intitulada Liber de sanctitate meritorum et gloria miraculorum beati Karoli Magni, que pode ser considerado um texto hagiográfico, independentemente da questão do grau de santidade de Carlos Magno, dado que foi redigido pouco depois da canonização do imperador pelo anti-papa Pascoal III, em 1165. A redacção desta obra está relacionada com mais um conflito político entre o Papa e o Imperador do Sacro Império romano-germânico.

A ambição do imperador Frederico Barba-Roxa levou-o a abrir as hostilidades com o Papa Adriano IV. O motivo para essa contenda era novamente o direito de investidura. $\mathrm{O}$ conflito agudizou-se sobretudo entre o imperador e Alexandre III, sucessor de Adriano IV. Paralelamente à eleição de Alexandre III, os partidários do imperador nomearam um anti-papa (Vítor IV) que se apoderou de Roma e logo recebeu o apoio de Frederico I. Toda a Europa e alguns prelados alemães confirmaram a obediência a Alexandre III, no sínodo de Tours de 1163. Nisto morre o anti-papa. Frederico Barba-Roxa pensa em aproveitar esta circunstância para se reconciliar com Alexandre III. Porém, não encontra nenhum religioso que queira dar sepultura a um excomungado. Frederico enfurece-se e nomeia um novo anti-papa que adopta o nome de Pascoal III. Perante isto, o povo e vários bispos alemães passam a reconhecer a legitimidade de Alexandre III.

54 Franz Brunhölzl, Histoire de la Littérature Latine du Moyen Âge, [1: L'époque mérovingienne; 2: La fondation de l'Europe à l'époque carolingienne] trad. de l'allemand par Henri Rochais; compléments bibliographiques pour l'édition française par Jean-Paul Bouhot, 2 vols, Louvain-la-Neuve, 1991, tom. I, vol. 2, p. 78.

A obra-prima de Eginardo exerceu forte influência ao longo de toda a Idade Média, e inclusivamente até à nossa época. Como afirma Brunhölzl, "[...] la Vita Karoli Magni s'est aussi acquis, par delà l'époque de l'Humanisme et de la grande Renaissance, dans tous les siècles de l'époque moderne, une grande réputation qu'elle a conservée jusqu'à nos jours et qui s'affirme même à l'examen lucide de la science moderne de l'histoire", ibid., p. 79. Norden considera Eginardo um precursor dos elegantes escritores do Renascimento italiano. Cf. Eduard Norden, Die antike Kunstprosa vom VI. Jahrhundert v. Chr. bis in die Zeit der Renaissance, 2 vols, Darmstadt, 1958, pp. 694 sq e 749. 
Cada vez mais solitário e enfraquecido, Frederico concebe um estratagema para reconquistar a simpatia do povo germânico: propõe ao anti-papa a canonização de Carlos Magno. Na sequência dessa proposta, foi redigida a referida obra hagiográfica que visava dois objectivos muito precisos. Em primeiro lugar, servia o propósito de Frederico I justificando a canonização de Carlos Magno. Este acto demagógico de elevar às honras dos altares uma figura tão prestigiada e tão popular era um acontecimento atraente para os Cristãos e despertava nos fiéis do Império os seus sentimentos nacionalistas. Assim, a canonização de Carlos Magno conjugava na mesma pessoa interesses políticos e religiosos.

Por outro lado, a nova biografia do "santo" Carlos Magno servia de propaganda aos interesses imperiais, uma vez que a santidade imperial visava sobrepor implicitamente a linhagem e, consequentemente, a pessoa de Frederico I acima do poder pontifício. Não lhe bastava ter entre os seus antepassados santos como Arnulfo de Metz, o patriarca dos Carolíngios, ou o imperador Henrique II. A existência de um santo dinástico do calibre de Carlos Magno contribuía para a consolidação de uma certa ideia de que esse santo conferia virtudes santificantes e alguma razão divina à acção dos seus descendentes.

Já poucos anos antes Otão de Freising, parente do imperador Frederico Barba-Roxa, celebrara na sua crónica, e a propósito da pessoa de Henrique III, o regresso da dignitas imperialis ad generosum et antiquum germen Karoli. Também Godofredo de Viterbo se refere a Frederico, nos seus Gesta Friderici, fazendo alusão ao prestígio da estirpe dos Carolíngios: natus ex clarissima progenie Karulorum.

Curiosamente, nesta disputa entre Frederico I e o Papa Alexandre III, o Sucessor de S. Pedro recebeu o apoio explícito de Tomás Becket, arcebispo de Cantuária. Também ele experimentava na Inglaterra os efeitos perversos de pretensões idênticas às do Barba-Roxa: o Plantageneta Henrique II ambicionava reduzir os poderes da Igreja e apoderar-se dos seus bens ${ }^{56}$. Em 1170, Tomás Becket pagou com a vida a oposição destemida e determinada por ele movida ao poder real. João de Salisbúria, amigo e secretário de Becket, exaltou, desde logo, a figura e a acção do arcebispo martirizado. Em 1172, Garnier de Pont-Sainte-Maxence viaja para Inglaterra e redige uma Vida de S. Tomás, o Mártir. Em 1173-4, William Fitz Stephen, um clérigo londrino amigo de Becket, que além de ser seu capelão e assistente judicial em Cantuária foi testemunha presencial do assassínio, redigiu também

Sobre Tomás Becket, vd. sobretudo F. Barlow, Thomas Becket, London, 1986. 
uma Vita onde nos relata a hórrida agonia do arcebispo, em torpe sangue envolta, sem poupar os mais cruentos e atrozes pormenores de acto tão cobarde. Em 1173, apenas três anos volvidos sobre a sua morte, é o próprio Papa Alexandre III que canoniza este novo mártir da Igreja. Imediatamente se registaram milagres junto ao túmulo do mártir. Desde logo começaram a afluir peregrinos "from every shires ende / of Engelonde... / the hooly blisful martir for to seke / that hem hath holpen whan that they were seeke" nas palavras de Chaucer, no prólogo às suas Canterbury Tales. E Cantuária transformou-se num dos mais importantes locais de peregrinação da Idade Média. A um processo tão rápido não terá sido alheio, por um lado, o desejo da Igreja em conter a ambição do Plantageneta levando-o ao arrependimento, como efectivamente aconteceu, mas também, por outro lado, algum aproveitamento político da opinião pública europeia, chocada com morte tão cruel, no sentido de a dirigir contra Frederico I, enfraquecendo, assim, os apoios que este ainda conservava. Não esqueçamos que Tomás Becket foi morto com base no mesmos motivos que opunham Alexandre III ao imperador germânico.

A importância do prestígio social e da presença protectora da santidade na linhagem instigava os familiares de pessoas com fama de santidade, designadamente os reis, a obter a canonização oficial desses santos dinásticos. Assim se compreende que Charles de Anjou não só promovesse a causa de seu irmão Luís IX, o futuro S. Luís, Rei de França, como também procurasse obter a canonização de Luís de Toulouse, seu filho (e sobrinho de S. Luís), ainda que o próprio Charles II se tivesse oposto à vocação do filho.

De um modo geral, os processos de canonização de santos dinásticos eram bem encaminhados e tinham melhores hipóteses de serem bem sucedidos. Todavia, Roma também manifestava as suas preferências pelas casas reais europeias, consoante as alianças políticas. Como se compreende, a partir dos exemplos do séc. XII, que desenvolvemos anteriormente, motivos políticos faziam com que as causas promovidas pelos Hohenstaufen ou pelos Plantagenetas não fossem tão bem sucedidas quanto as que eram emanadas das chancelarias de Andessa ou de Anjou ${ }^{57}$. Se, na bula de canonização de S. Luís, o Papa Bonifácio VIII enfatiza não só a cruzada contra os Sarracenos, mas também a expulsão dos hereges de França, duas medidas que vinham ao encontro da política de Roma e que esta gostaria de ver imitadas pelas outras nações cristãs, a canonização de Santa Isabel da Hungria, por exemplo,

Vd. Michael Goodich, Vita Perfecta: the Ideal of Sainthood in the thirteenth Century, Stuttgart, 1982, p. 186. 
foi precedida de cartas de príncipes, arcebispos e abades que representavam a coalição anti-Hohenstaufen.

De facto, em alguns casos, a canonização de determinadas pessoas era dificultada por razões políticas. Não estava em causa qualquer aspecto relacionado com o retrato do canonizando, mas sim com atitudes ou orientações dúbias, do ponto de vista doutrinário ou teológico, dos respectivos partidários ${ }^{58}$. Mas, inversamente, a hagiografia também servia a política de ataque às heresias. Tomás Agni de Lentino, biógrafo de Pedro de Verona, um frade dominicano assassinado em Milão pelos Cátaros, pôs em relevo a luta que o santo conduziu contra os Gibelinos. A este que foi o segundo santo canonizado na história dos Dominicanos, após o seu fundador, sucederam-se muitos outros membros da Ordem dos Pregadores, sobretudo inquisidores, vítimas dos hereges, Cátaros, Arnaldistas, Gibelinos, e dos Sarracenos. Estes novos mártires animavam, com renovado fôlego, a cruzada dos Dominicanos contra as heresias. Efectivamente, a Ordem dos Pregadores havia sido concebida expressamente no intuito de combater a heresia através de actos e palavras. Não admira, pois, que os assassinatos dos Dominicanos tenham aberto o caminho à Inquisição. Foram tomadas medidas legislativas que conferiam as condições necessárias ao desempenho da Inquisição. Em alguns casos, os poderes civis abrogaram leis que afectavam os interesses da Igreja ou que colidiam com a Fé, conferindo, desta forma, poderes quase absolutos aos Inquisidores. Assim, as canonizações dos frades assassinados reforçavam os poderes dos Dominicanos, os principais responsáveis pela Inquisição.

Enquanto os mártires dominicanos sucumbiam em solo europeu às mãos dos hereges, já os mártires franciscanos, imbuídos do espírito missionário, haviam perecido em terras de missão, no Sul da Hispânia e no Norte de África ${ }^{59}$. Mas, no caso das hagiografias franciscanas, não há nenhuma que tenha suscitado tanta polémica e tenha sido alvo de tantas versões como a de $\mathrm{S}$. Francisco. As muitas variantes hagiográficas do Poverello de Assis foram influenciadas pelo conflitos existentes entre duas correntes principais dos seus seguidores: a dos "espirituais", mais conservadores e que recusavam o afastamento do primitivo ideal evangélico e se opunham a qualquer reinterpretação da Regra, e a chamada "Comunidade", facção mais

Vd. os exemplos de Salimbene de Adam apresentados por Michael Goodich, Vita Perfecta: the Ideal of Sainthood in the thirteenth Century, Stuttgart, 1982, p. 194, n. 43.

Lembremos que o próprio Santo António ingressou na Ordem dos Frades Menores entusiasmado com o exemplo dos mártires de Marrocos e se dirigiu para o Norte de África, disposto a sofrer o martírio. 
conventual, mais progressista e que preconizava uma adaptação da Ordem a um apostolado mais próximo do povo. Mais uma vez, a hagiografia procurava justificar e determinar a orientação estratégica da Ordem dos Frades Menores.

Em alguns casos, o textos hagiográficos serviam políticas de natureza essencialmente religiosa. Suspeita-se, por exemplo, que a Vita S. Geraldi redigida pelo arcediago Bernardo e futuro Bispo de Coimbra terá sido redigida para selar, por meio da sua santidade e dos seus milagres, a aprovação divina da acção reformadora do Bispo de Braga, designadamente no tocante à substituição da liturgia moçárabe pelas tradições e costumes litúrgicos romanos ${ }^{60}$.

Momentos há onde se verifica uma fusão dos objectivos religiosos e políticos. Esses casos ocorrem sobretudo quando a propagação da Fé coincide com a dilatação do império, ou seja, quando o santo é militar e se encontra ao serviço de uma causa dupla. Nestas situações há um outro aspecto a considerar. É que só são considerados mártires os Cristãos que comprovadamente sofreram a morte pela Fé e não por motivos políticos. A dificuldade em se distinguir até que ponto alguém foi morto devido à sua crença religiosa ou por força da sua condição política agudiza-se assim que se verifica uma convergência dos dois interesses - político e religioso - como é o caso das cruzadas, por exemplo ${ }^{61}$. Nestes casos, o hagiógrafo procura salientar a condição de crente do biografado.

A partir do séc. XIII, na sequência da importância atribuída ao novo modelo de espiritualidade iniciado por S. Francisco de Assis, assumiu cada vez mais relevância a vivência das virtudes e dos princípios evangélicos em detrimento dos poderes taumatúrgicos do santo. As hagiografias passaram a reflectir essa evolução de mentalidade não só na caracterização directa, mas sobretudo na caracterização indirecta.

Cf. J. Mattoso, "Le Portugal de 950 à 1550”, Hagiographies (Corpus Christianorum), sous la direction de Guy Philippart, Turnhout, 1996, vol. 2, pp. 82-102.

61 Modernamente essa dificuldade é experimentada quando se trata de cristãos que sucumbiram aos regimes nazi e comunista. Semelhante é o caso de D. Oscar Romero, Bispo de El Salvador, que, além de ter sido morto durante uma celebração eucarística, fez prevalecer o seu amor pelos pobres e pelos oprimidos, de acordo com a sua condição de cristão, sobre o mero sentido de justiça social, a tal ponto que, antes de ser morto, havia oferecido a sua vida pelo seu rebanho, designadamente pelos seus irmãos mais pobres. Como bem salientou K. Woodward, D. Oscar Romero não pode ser qualificado de mártir da justiça, como foi $e$. $g$. Martin Luther King, mas sim de mártir da Igreja. Vd. Kenneth L. Woodward, Making Saints, London, 1996, pp. 36-49 , sobretudo pp. 45 sq. 
Como refere Jacques Le Goff, “a partir dos séculos XII e XIII, foi-se passando cada vez mais da santidade de funções para a santidade por imitação de Cristo [...]. A santidade espiritualizou-se e associou-se mais ao estilo de vida do que à condição social, à moralidade mais do que aos milagres" ${ }^{\prime \prime 2}$. André Vauchez acrescenta, referindo-se ao acesso crescente da plebe à santidade na zona mediterrânica: "Assim nos surge em toda a sua plenitude o processo de interiorização da santidade, que agora se baseia - para lá das diferenças de classe social - na comum devoção à humanidade de Cristo e no desejo de o seguir, imitando-o"63.

Dos sécs. XIV-XV em diante, as hagiografias já são redigidas essencialmente com o propósito de fornecerem "material adequado para os processos de beatificação e de canonização",64.

Vd. Jacques Le Goff, F. Cardini, E. Castelnuovo, et alii (edd.), O Homem Medieval, Direcção de Jacques Le Goff, Lisboa, 1989, p. 24.

Vd. André Vauchez, "O Santo", O Homem Medieval (ed. Jacques Le Goff et alii), Direcção de Jacques Le Goff, Lisboa, 1989, pp. 211-230, localizando-se a citação na p. 220.

$V d$. Réginald Grégoire, Manuale di agiologia. Introduzione alla letteratura agiografica (Bibliotheca Montisfani, 12), Fabriano, 1987, p. 35. 
(Página deixada propositadamente em branco) 


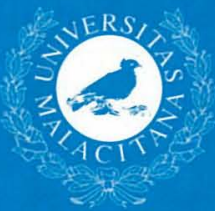

